A N N A LE S

UNIVERSITATIS MARIAE CURIE-SKŁODOWSKA

LUBLIN - POLONIA

VOL. LXIX, z. 1-2

SECTIO F

Uniwersytet Śląski w Katowicach

Wydział Nauk Społecznych Instytut Historii

MARCIN SMIERZ

\title{
Znaczenie potencjału przemysłowego polskiego Górnego Śląka w planach III Rzeszy w latach 1933-1945
}

The Importance of the Industrial Potential of Polish Upper Silesia in the Plans of the Third Reich, 1933-1945

\section{STRESZCZENIE}

Artykuł ma na celu wskazanie, jakie znaczenie miał przemysł górniczo-hutniczy w polskiej części Górnego Śląska w polityce III Rzeszy przed wybuchem i w trakcie II wojny światowej. Podstawą jest określenie przyczyn, które spowodowały wzrost zainteresowania Górnym Śląskiem w drugiej połowie lat 30. XX w. (militaryzacja, pobudzenie gospodarki przez szereg inwestycji państwowych, a w efekcie wzrost zapotrzebowania na węgiel i stal oraz próba gospodarczego uniezależnienia się od innych państw - autarkia). Tekst został podzielony na trzy części, w których omówiono gospodarcze i polityczne skutki podziału Górnego Śląska po 1921 r., pozycję ekonomiczną Górnego Śląska w polityce III Rzeszy w latach 1933-1939 oraz podczas II wojny światowej. Podkreślono także rywalizację między „starymi”, funkcjonującymi przez co najmniej kilkadziesiąt lat, górnośląskimi koncernami i ich właścicielami a właścicielami dużych firm z branży stalowej czy górniczej, funkcjonującymi do tej pory w Zagłębiu Ruhry czy Saary. Przykładem takich koncernów, penetrujących górnośląski, ale również zagłębiowski przemysł, są IG Farbenindustrie A.G. czy koncerny Friedricha Flicka i Roberta Röchlinga. Niniejszy tekst został oparty na materiałach zgromadzonych w trakcie kwerendy archiwalnej w Archiwum Państwowym w Katowicach i jego oddziale w Gliwicach oraz uzupełniony o literaturę przedmiotu.

Słowa kluczowe: Górny Śląsk; przemysł; dwudziestolecie międzywojenne; Trzecia Rzesza 


\section{WPROWADZENIE}

Celem niniejszego artykułu jest wskazanie, jakie znaczenie miał przemysł górniczo-hutniczy polskiej części Górnego Śląska w polityce III Rzeszy przed wybuchem i podczas II wojny światowej. Podstawą tekstu jest określenie przyczyn, które spowodowały wzrost zainteresowania Górnym Śląskiem w drugiej połowie lat 30. XX w., takich jak militaryzacja, pobudzenie gospodarki przez szereg inwestycji państwowych, a co za tym idzie - zapotrzebowanie na węgiel i stal, oraz próba gospodarczego uniezależnienia się od innych państw.

Opracowanie zostało podzielone na trzy części. W pierwszej zostały omówione skutki podziału Górnego Śląska po powstaniach i plebiscycie oraz działania polityczne przywódców III Rzeszy, których celem była rewizja granic i przejęcie potencjału przemysłowego innych krajów, a w efekcie wzmocnienie pozycji gospodarczej na rynkach Europy Środkowo-Wschodniej. W drugiej przedstawiono Górny Śląsk podczas II wojny światowej, od momentu zajęcia polskiej części Górnego Śląska przez wojska niemieckie, przez maksymalizację produkcji i wręcz rabunkowej gospodarki przy jednoczesnym ograniczeniu nakładów na inwestycje. Sporo miejsca poświęcono również nacjonalizacji przemysłu i innych gałęzi gospodarki i jego zarządzaniu według decyzji politycznych, a nie rynkowych.

Podkreślono ponadto rywalizację między „starymi” koncernami i ich właścicielami a właścicielami dużych firm z branży stalowej czy górniczej, funkcjonujących do tej pory w Zagłębiu Ruhry czy Saary. Przykładem takich koncernów, penetrujących górnośląski, ale też zagłębiowski przemysł, są IG Farbenindustrie A.G. czy koncerny Friedricha Flicka i Roberta Röchlinga.

\section{GOSPODARCZE I POLITYCZNE SKUTKI PODZIAŁU GÓRNEGO ŚLĄSKA PO PLEBISCYCIE I POWSTANIACH ŚLĄSKICH}

Trzy powstania oraz plebiscyt na Górnym Śląsku były jedną z konsekwencji załamania relacji w stosunkach polsko-niemieckich. W efekcie, wraz z zatwierdzeniem decyzji przez Radę Ambasadorów 20 października 1921 r., nastąpił podział górnośląskiego obszaru plebiscytowego między Polskę i Niemcy ${ }^{1}$. W jego wyniku w Polsce w skład nowo utworzonego autonomicznego województwa śląskiego weszły dotychczasowe powiaty: katowicki, pszczyński, rybnicki, część tarnogórskiego i lublinieckiego oraz miasta - Katowice, Królewska Huta, Rybnik i Pszczyna ${ }^{2}$. Po stronie niemieckiej znalazły się z kolei powiaty: kluczborski, ole-

${ }^{1} 12$ października 1921 r. na forum zgromadzenia Ligi Narodów przyjęto francuski projekt podziału Górnego Śląska między Polskę i Niemcy. Szerzej: J. Przewłocki, Stosunek mocarstw zachodnio-europejskich do problemów Górnego Ślaska w latach 1918-1939, Warszawa - Kraków 1978.

${ }^{2}$ Oprócz tego w 1920 r. w skład województwa śląskiego weszła część podzielonego między 
śnieński, opolski, kozielski, głubczycki, raciborski, prudnicki, strzelecki, toszecko-gliwicki oraz miasta - Bytom, Zabrze i Gliwice. Podział ten pod względem terytorialnym pozostawiał 2/3 powierzchni Górnego Śląska po stronie państwa niemieckiego, lecz bardziej uprzemysłowiona część została przyznana państwu polskiemu. Ogólne skutki podziału Górnego Śląska przedstawia tab. 1.

Tab. 1. Podział potencjału przemysłowego Górnego Śląska w październiku $1921 \mathrm{r}$.

\begin{tabular}{|l|c|c|}
\hline \multicolumn{1}{|c|}{ Rodzaj przemyslu } & Polska & Niemcy \\
\hline Kopalnie węgla & 53 & 14 \\
\hline Huty żelaza & 5 & 4 \\
\hline Huty cynku, ołowiu i srebra & 18 & - \\
\hline Elektrownie & 8 & 61 \\
\hline
\end{tabular}

Źródło: F. Biały, Górnośląski Związek Przemysłowców Górniczo-Hutniczych (1914-1932), Wrocław - Warszawa - Kraków 1967, s. 191.

Mimo ustanowienia na Górnym Śląsku granicy państwowej między Polską i Niemcami, stosunki w strukturze własnościowej przemysłu górniczo-hutniczego (ciężkiego) nie uległy w tym czasie istotnym zmianom. Szacuje się, że udział niemieckich akcjonariuszy w górnośląskim przemyśle, wartym wówczas 1,46 bln marek niemieckich, wynosił 75\%, czyli 1,095 bln marek. Jeszcze większy udział kapitału niemieckiego był widoczny w strukturze własności ziemskiej. Z przypadłych Polsce 169903 ha (52,5\% powierzchni) tylko 24137 ha (14,3\%) znajdowało się w rękach polskich, zaś pozostałe 145766 ha $(85,7 \%)$ należało do niemieckich posiadaczy ziemskich ${ }^{3}$.

Utrata potencjału przemysłowego Górnego Śląska, zwłaszcza w zakresie bazy surowcowej (węgiel kamienny), doprowadziła zarówno do obniżenia zdolności przemysłowej osłabionej po przegranej wojnie gospodarki niemieckiej, jak i stała się jedną z głównych przyczyn napięcia w stosunkach polsko-niemieckich ${ }^{4}$.

Polskę i Czechosłowację Śląska Cieszyńskiego z Cieszynem i Bielskiem (powiaty: bielski i cieszyński).

${ }^{3}$ Głównymi właścicielami ziemskimi były wielkie rody szlacheckie, np. Ballestremowie, Donnersmarckowie czy książęta von Pless (Hochberg) i Hohenlohe-Ingelfingen z Koszęcina, posiadające swoje dobra w ramach fideikomisów istniejących na Górnym Śląsku właściwie do 1945 r. (wyjątek stanowi fideikomis książąt pszczyńskich rozwiązany ustawą Sejmu RP z dnia 7 sierpnia 1937 r., Dz.U. 1937, nr 60, poz. 474). Zob. M. Grzyb, Narodowościowo-polityczne aspekty przemian stosunków własnościowych i kadrowych w górnośląskim przemyśle w latach 1922-1939, Katowice 1978, s. 31.

${ }^{4} \mathrm{Na}$ arenie międzynarodowej przez kilka następnych lat podkreślano krzywdę i upokorzenie narzuceniem traktatu wersalskiego oraz domagano się rewizji jego postanowień. Zob. K. Błachut, Polsko-niemieckie stosunki gospodarcze w latach 1919-1939, Wrocław 1975, s. 268. 
Krótko po podziale Górnego Śląska doszło do zmian w strukturze organizacyjnej koncernów przemysłowych. $Z$ jednej strony nastąpiła masowa wyprzedaż małych zakładów, głównie z branży usług i rzemiosła. W dalszym ciągu jednak w przemyśle ciężkim (górnictwie węglowym oraz hutnictwie cynku i żelaza) większościowym akcjonariuszem pozostawał kapitał niemiecki. Zmieniła się jedynie struktura organizacyjna przez tworzenie nowych spółek i firm zależnych finansowo i decyzyjne od central położonych po niemieckiej stronie granicy (głównie w Gliwicach, Bytomiu i we Wrocławiu) ${ }^{5}$. Decyzje o tworzeniu firm zależnych wynikały z pobudek politycznych i niechęci do nowo odrodzonego państwa polskiego ${ }^{6}$. Taki układ własnościowy i organizacyjny był powszechny dla całego przemysłu ciężkiego na polskim Górnym Śląsku. Wynikał on z kilku przyczyn. Pierwszą były względy polityczne. Przemysł znajdował się w $75 \% \mathrm{w}$ rękach niemieckich akcjonariuszy, którzy nie byli zadowoleni z podziału Górnego Śląska i zerwania powiązań ekonomiczno-technicznych na skutek wprowadzenia sztucznej granicy państwowej, które zaowocowały spadkiem poziomu produkcji w pierwszych latach po podziale, a nawet upadkiem szeregu małych zakładów przemysłowych, których właściciele opuścili tereny województwa śląskiego ${ }^{7}$. Drugą przyczyną była potrzeba dostosowania istniejących i nowych spółek do nowo tworzonego polskiego systemu prawnego, przy jednoczesnym zachowaniu realnego wpływu na zarządzanie nimi. Korzystne przy tym były przepisy konwencji genewskiej dla Górnego Śląska z 15 maja 1922 r., która zapewniała swobodę gospodarczą (specjalne taryfy celne, nakaz importu polskiego węgla przez trzy lata) i chroniła własność (ograniczenia w odpłatnym wywłasz-

${ }^{5}$ Mimo starań władz polskich przez cały okres dwudziestolecia międzywojennego w górnośląskim przemyśle dominował kapitał niemiecki. Jego przeciwwagę miało stanowić wejście kapitału francuskiego w górnictwie węglowym i hutnictwie cynku (Skarboferm. Polskie Kopalnie Skarbowe na Górnym Śląsku, Spółka Dzierżawna S.A. w Katowicach i Tarnoferm. Polska Huta Skarbowa Ołowiu i Srebra w Strzybnicy, Spółka Dzierżawna S.A.), który na drodze umowy z polskim rządem w zamian za kredyty objął we władanie kopalnie i hutę należącą przed podziałem Górnego Śląska do państwa niemieckiego. Z kolei w 1926 r. w górnośląskim przemyśle cynkowym znaczną pozycję dzięki wykupieniu udziałów w koncernie Giesche S.A. uzyskał amerykański koncern Harimmanna. Zob. J. Popkiewicz, F. Ryszka, Przemyst ciężki Górnego Śląska w gospodarce Polski międzywojennej (1922-1939), Opole 1959, s. 76-85, 190-195.

${ }^{6}$ Zarówno hrabia Wolfgang von Ballestrem, jak i jego syn Nikolaus w okresie powstań śląskich i plebiscytu jawnie finansowali działalność niemieckiej organizacji paramilitarnej Freikorps, a także popierali pozostawienie Górnego Śląska w Niemczech. Zob. J. Jaros, Tajemnice górnoślaskich koncernów, Katowice 1988, s. 29-30.

${ }^{7} \mathrm{~W}$ wyniku tego na 22 największe spółki przemysłu górniczo-hutniczego struktura majątkowa pozostała niezmieniona w pięciu po stronie niemieckiej i sześciu po stronie polskiej, zaś w pozostałych 11 wprowadzenie polsko-niemieckiej granicy spowodowały zmiany w strukturze organizacyjnej i własnościowej. Zob. G. Wende, Die Auswirkung der Grenzziehung auf die Oberschlesische Montanindustrie, Stuttgart 1932, s. 27. 
czeniu przez państwo polskie przez okres 15 lat) ${ }^{8}$. Z kolei tworzenie zakładów filialnych, mających co prawda osobowość prawną, miało na celu uzależnienie firm od decyzji zapadających w niemieckich siedzibach zarządów koncernów. Przy okazji umożliwiało to szybki odpływ kapitału, którego celem było spowodowanie recesji gospodarczej, a w perspektywie szansę na ponowne złączenie Górnego Śląska pod egidą Niemiec. Ponadto umożliwiały one płacenie podatków w Niemczech ${ }^{9}$.

Istotnym narzędziem nacisku na rząd i władze województwa śląskiego były organizacje skupiające firmy przemysłowe z branży górniczo-hutniczej, takie jak np. Górnośląski Związek Przemysłowców Górniczo-Hutniczych (1914/19221932) i Górnośląska Konwencja Węglowa (1905/1922-1932). Organizacje te miały charakter karteli gospodarczych, które skupiając większą część produkcji w danej branży przez dyktowanie cen surowców i towarów, ograniczały konkurencję i wymuszały korzystne ulgi podatkowe i taryfy kolejowe.

Podział Górnego Śląska w dłuższej perspektywie zaowocował skomplikowaniem i pogorszeniem kontaktów gospodarczych między Polską a Niemcami praktycznie w całym okresie dwudziestolecia międzywojennego. Pierwsze jego symptomy były widoczne już w latach 1921-1922, kiedy nastąpił spadek produkcji i doszło do masowych zwolnień w zakładach przemysłowych. Był to efekt sztucznego podtrzymywania przez Niemców koniunktury w przemyśle w okresie plebiscytu celem przekonania głosujących Ślązaków do pozostania w ramach Republiki Weimarskiej. Kolejne okresy załamań w przemyśle górnośląskim obrazuje tab. 2.

Praktycznie w każdym z tych okresów nastąpiło zahamowanie gospodarczych kontaktów między Polską a Niemcami. Najbardziej widoczne konsekwencje były po wojnie celnej i w okresie kryzysu gospodarczego, kiedy niemiecki przemysł górniczo-hutniczy został poddany gruntownemu procesowi reorganizacji i doinwestowania, czego największy efekt był widoczny w niemieckiej części Górnego Śląska, w której o kilkadziesiąt procent wzrósł poziom produkcji.

Władze polskie zdawały sobie sprawę z niebezpiecznej sytuacji, jaką była przewaga niemieckiego kapitału w przemyśle górnośląskim. Jeszcze w 1922 r. podjęły działania mające na celu zachęcenie zachodnioeuropejskich przemysłow-

${ }^{8}$ Dz.U. 1922, nr 44, poz. 371. Szerzej na ten temat: M. Smierz, Polsko-niemiecka konwencja genewska z dnia 15 maja 1922 roku. Założenia i realizacja, [w:] Vade Nobiscum, t. III: Historia dyplomacji, Łódź 2010, s. 79-84.

${ }^{9}$ Przyczyn odpływu niemieckiego kapitału z polskiego Śląska było kilka. Z jednej strony był to interes polityczny, którego celem było załamanie gospodarcze II RP i docelowo wcielenie Górnego Śląska do Niemiec. Z drugiej były to względy gospodarcze. Polska, będąca w głównej mierze krajem rolniczym, nie posiadała chłonnego rynku mogącego przyjąc całą krajową produkcję węgla i stali. Zmuszało to koncerny do sprzedaży produktów na rynkach zagranicznych pod dużą presją konkurencji, po cenach dumpingowych. Na rynku polskim z kolei starano się sprzedawać te same produkty po cenach zawyżonych lub - żeby uniknąć podatków - wykazywać stale ujemny bilans. 
Tab. 2. Etapy załamania kontaktów gospodarczych dla Górnego Śląska na tle konfliktów Polski z Niemcami w latach 1923-1939

\begin{tabular}{|l|l|l|}
\hline \multirow{2}{*}{ Okres kryzysu } & \multicolumn{2}{|c|}{ Najważniejsze skutki } \\
\cline { 2 - 3 } & \multicolumn{1}{|c|}{ Polska } & \multicolumn{1}{|c|}{ Niemcy } \\
\hline $\begin{array}{l}\text { Hiperinflacja jako } \\
\text { wynik powojennego } \\
\text { kryzysu finansowego } \\
(1923-1924)\end{array}$ & $\begin{array}{l}\text { Wprowadzenie nowej waluty - złoty } \\
\text { polski } \\
\text { Upadek małych przedsiębiorstw } \\
\text { Ożywienie eksportu polskiego węgla }\end{array}$ & $\begin{array}{l}\text { Spadek rentowności zakładów } \\
\text { przemysłowych w niemieckiej } \\
\text { czéci Górnego Śląska } \\
\text { Strajki w Zagłębiu Ruhry } \\
\text { i koniecznośck eksportowania } \\
\text { węgla z Polski }\end{array}$ \\
\hline $\begin{array}{l}\text { Niemiecko-polska } \\
\text { wojna celna } \\
(1925-1930)\end{array}$ & $\begin{array}{l}\text { Spadek eksportu polskiego węgla do } \\
\text { Niemiec } \\
\text { Nałożenie cła na polskie towary } \\
\text { Spadek cen i produkcji surowców } \\
\text { i wyrobów przemysłowych } \\
\text { Administracyjne utrudnienia dla } \\
\text { przewozu towarów przez granicę } \\
\text { niemiecką } \\
\text { Wzrost konkurencyjności na rynkach } \\
\text { zagranicznych }\end{array}$ & $\begin{array}{l}\text { Uniezależnienie od polskiego } \\
\text { eksportu } \\
\text { Spadek inwestycji w przemysł } \\
\text { na polskim Górnym Śląsku }\end{array}$ \\
\hline $\begin{array}{l}\text { Wielki kryzys } \\
\text { gospodarczy } \\
\text { (1929-1935) }\end{array}$ & $\begin{array}{l}\text { Wycofywanie niemieckiego kapitału } \\
\text { z Górnego Śląska } \\
\text { Spadek produkcji i masowe bezrobocie }\end{array}$ & $\begin{array}{l}\text { Szereg inwestycji w rodzimy } \\
\text { przemysł, uniezależnienie się } \\
\text { od importu } \\
\text { Wzrost konkurencyjności na } \\
\text { rynkach zagranicznych }\end{array}$ \\
\hline $\begin{array}{l}\text { Agresywna polityka } \\
\text { Hitlera wobec Polski } \\
\text { w przededniu II wojny } \\
\text { światowej } \\
(1938-1939)\end{array}$ & $\begin{array}{l}\text { Wzrost produkcji i pobudzenie } \\
\text { krajowego rynku }\end{array}$ & $\begin{array}{l}\text { Inwestycje w przemyśle } \\
\text { zbrojeniowym }\end{array}$ \\
\hline
\end{tabular}

Źródło: opracowanie własne.

ców do inwestowania w polski przemysł. Jednym z pierwszych efektów tych działań było powstanie 22 lutego 1922 r. polsko-francuskiej spółki akcyjnej „Polskie Kopalnie Skarbowe na Górnym Śląsku, Spółka Dzierżawna S.A. w Królewskiej Hucie” („Skarboferm”) ${ }^{10}$ oraz spółki francusko-polskiej „Polska Huta Skarbowa Ołowiu i Srebra, Spółka Dzierżawna S.A. w Strzybnicy"11. Spółki te powstały w oparciu o przejęty przez Skarb Państwa polskiego majątek obejmujący

${ }^{10}$ Archiwum Państwowe Katowice, SKARBOFERM Spółka Dzierżawna Polskich Kopalń Skarbowych na Górnym Ślasku Spótka Akcyjna w Katowicach, zesp. 334; Z. Szmidtke, „Skarboferm” 1922-1939. Zwiazki polityki z gospodarka, Opole 2005.

${ }^{11}$ Archiwum Państwowe Katowice, Polska Huta Skarbowa Otowiu i Srebra w Strzybnicy, zesp. 1533. 
kopalnie węgla kamiennego „König” („Król”), „Rheinbabenschächte” („Bielszowice”), „Knurow” wraz z koksownią („Knurów”), kopalnie rud srebra i ołowiu w rejonie Tarnowskich Gór oraz hutę cynku, srebra i ołowiu „Friedrichhütte” („Fryderyk”) w Strzybnicy jako dzierżawa na 36 lat $^{12}$. W obu przypadkach udziałowcami po $50 \%$ byli akcjonariusze francuscy i polski Skarb Państwa. Innym dużym inwestorem był amerykański trust metali kolorowych "Anakonda Cooper Mining Co.”, który w latach 1925-1926 przejął 100\% akcji spółki „Giesche S.A.” (największego w Polsce producenta cynku), znajdującej się wówczas w trudnej sytuacji finansowej ${ }^{13}$.

Należy dodać, że ważną rolę w przemyśle górnośląskim pełniła również Państwowa Fabryka Związków Azotowych w Królewskiej Hucie ${ }^{14}$. Ponadto na Górnym Śląsku znajdowało się kilka fabryk papieru i celulozy (Mikołów, Kalety, Czułów) oraz zakłady produkujące materiały wybuchowe - Lignoza S.A. (Lignose AG - posiadająca fabryki w Krywałdzie, Bieruniu Starym i Pniowcu) i Górnośląskie Zakłady Materiałów Wybuchowych w Łaziskach Górnych (OSWAG AG), której udziałowcem był m.in. książę pszczyński ${ }^{15}$.

\section{POZYCJA EKONOMICZNA GÓRNEGO ŚLĄSKA W POLITYCE III RZESZY W LATACH 1933-1939}

Wraz z dojściem do władzy w Niemczech Adolfa Hitlera w styczniu 1933 r., w krótkim czasie przystąpiono do realizacji programu wyjścia z kryzysu gospodarczego przez wdrożenie pierwszego planu 4-letniego (1933-1936), którego celem z jednej strony był szeroko zakrojony program inwestycyjny (rozwój infra-

${ }^{12}$ Własność wymienionych zakładów przemysłowych ze skarbu pruskiego na Górnym Śląsku na rzecz polskiego Skarbu Państwa została przeniesiona w oparciu o art. 256 traktatu wersalskiego. Zob. J. Popkiewicz, F. Ryszka, op. cit., s. 86-87.

${ }^{13}$ Ibidem, s. 206-209.

${ }^{14}$ W 1916 r. z inicjatywy władz niemieckich oraz koncernu Bayerische Stickstoffwerke AG zostały uruchomione Zakłady Azotowe w Królewskiej Hucie (od 1934 r. w Chorzowie). Zakład ten jako pierwszy w Niemczech wykorzystał na skalę przemysłową proces Habera do produkcji nawozów i materiałów wybuchowych, wykorzystując do tego powietrze, wodę i węgiel. Po I wojnie światowej zakłady zostały przejęte przez rząd polski i ze względu na strategiczne wówczas znaczenie były przedmiotem międzynarodowego sporu rozstrzyganego przez Stały Trybunał Sprawiedliwości Międzynarodowej przy Lidze Narodów. Ostatecznie w lipcu 1922 r. Zakłady Azotowe w Chorzowie zostały oficjalnie przejęte przez rząd polski, zaś w 1924 r. uzyskały osobowość prawną jako spółka pod nazwą „Państwowa Fabryka Związków Azotowych w Chorzowie sp. z o.o.”. W 1933 r. dokonano fuzji Państwowej Fabryki Związków Azotowych w Chorzowie i Fabryki Związków Azotowych w Mościcach k. Tarnowa. Do II wojny światowej zakład był największym kombinatem chemicznym w Polsce. Zaangażowani w rozwój przedsiębiorstwa byli m.in. prezydent Ignacy Mościcki (autor licznych patentów z zakresu chemii) i Eugeniusz Kwiatkowski. Zob. Zakłady Azotowe im. P. Findera - Chorzów, red. A. Topola, Katowice 1979.

${ }^{15}$ A. Sulik, Przemyst, [w:] Województwo śląskie (1922-1939), red. F. Serafin, Katowice 1996, s. 219-220. 
struktury drogowej, roboty publiczne i wspieranie nowych dziedzin technologicznych), zaś z drugiej ekspansja polityczno-gospodarcza (głównie w Europie Środkowo-Wschodniej i na Bałkanach) i dążenie do stworzenia mechanizmów samowystarczarczalnej gospodarki (autarkii). W dłuższej perspektywie głównym celem była odbudowa potencjału militarnego Niemiec i rewizja granic po przegranej I wojnie światowej.

W krótkim czasie szeroko zakrojone plany inwestycyjne pochłonęły wszelkie rezerwy siły roboczej oraz surowców. Przejęcie potencjału przemysłowego Austrii i Czechosłowacji w latach 1938-1939 nie przyniosło wyraźnej poprawy sytuacji gospodarczej, wzmocniło natomiast pozycję handlową III Rzeszy na rynkach w Europie Południowo-Wschodniej (Rumunia, Bułgaria) ${ }^{16}$. Mimo to ciągłe zbrojenia odbiły się na spadku wydajności pracy oraz przyczyniły się do ograniczenia eksportu, głównie węgla. Ponadto wprowadzono w tym okresie system racjonowania żywności. W tych okolicznościach ekspansja kosztem Polski, rozpoczęta we wrześniu 1939 r., była środkiem pokonania wielu trudności w poszczególnych gałęziach gospodarki. Pożądanym efektem niemieckich działań miało być zarówno uzupełnienie bazy surowcowej, jak i zasobów siły roboczej, potrzebnych w momencie mobilizacji niemieckich robotników do armii. Należy podkreślić, iż niemieckie zainteresowanie polskim potencjałem przemysłowym nie ograniczało się do Górnego Śląska, lecz objęło również Zagłębie Dąbrowskie i Zagłębie Krakowskie, mimo że były one pod względem zdolności produkcyjnej i technologii znacznie słabsze. Wynikało to ze spadku i ograniczenia możliwości produkcyjnych w Zagłębiu Ruhry i w niemieckiej części Górnego Śląska, gdzie $\mathrm{w}$ drugiej połowie lat 20. przeprowadzono modernizację zakładów przemysłowych $^{17}$. Tak szerokie zainteresowanie złożami polskiego węgla wynikało z zapotrzebowania na ten strategiczny surowiec $\mathrm{w}$ systemie zmilitaryzowanej niemieckiej gospodarki i z jego wykorzystywania nie tylko w hutnictwie czy energetyce, ale również w nowo rozwijanych gałęziach, takich jak produkcja gumy czy benzyny syntetycznej ${ }^{18}$. Ponadto przejęcie polskich zakładów i złóż mogłoby umoż-

${ }^{16}$ Idem, Przemysł ciężki rejencji katowickiej w gospodarce Trzeciej Rzeszy (1939-1945), Katowice 1984, s. 23-24.

${ }^{17}$ Archiwum Państwowe Gliwice, Grupa Okręgowa Górnictwo Węgla Kamiennego na Górnym Ślasku Grupy Gospodarczej Górnictwo w Gliwicach, zesp. 120, sygn. 323, bp, Analiza porównawcza zdolności produkcyjnych i możliwości rozwojowych kopalń Zagłębia Ruhry i zachodniej części Górnego Śląska.

${ }^{18}$ Obie wymienione nowe gałęzie przemysłu były rozwijane w ramach planu 4-letniego (1936-1940). Pełnomocnikiem do jego wykonania był Reichsmarschall Hermann Göring. Głównym założeniem planu, obok redukcji bezrobocia, był rozwój przemysłu chemicznego, w tym wspomniana już produkcja włókien syntetycznych i syntetycznej benzyny, szeroki program robót publicznych, pobudzenie przemysłu samochodowego i budownictwa autostrad. Ponadto przewidywano rozwój sił zbrojnych przez zwiększenie liczebności armii i rozwój nowych rodzajów broni, które zostały Niemcom zabronione po ich klęsce w I wojnie światowej. Zob. W. Birkenfeld, Der syntetische 
liwić zwiększenie niemieckiego eksportu i w efekcie uzyskanie innych potrzebnych surowców, jak np. szwedzkiej rudy żelaza czy rumuńskiej ropy naftowej.

Realizacja inwestycji w ramach planu 4-letniego, w postaci budowy elektrowni, zakładów chemicznych (np. kompleksu zakładów koncernu Reichswerke Hermann Göring w Salzgitter), spowodowała zwiększenie zapotrzebowania na węgiel. Sytuacja gospodarcza dodatkowo pogorszyła się w sierpniu 1939 r. na skutek spadku zapasów węgla na zwałach oraz zmniejszenia zdolności produkcyjnej wywołanej mobilizacją części załóg do wojska. Zainteresowanie przejęciem zakładów przemysłowych w polskiej części Górnego Śląska oraz w Zagłębiu Dąbrowskim i Zagłębiu Krakowskim wykazywały także różne koncerny z niemieckiej części Górnego Śląska, często dawni właściciele tych przedsiębiorstw. Przejawem wspomnianego zainteresowania było zacieśnienie współpracy od połowy 1939 r. pomiędzy udziałowcami i dyrektorami koncernów hrabiów von Ballestrem (Graf von Ballestrem'sche Guterdirektion), Schaffgotsch (Gräflich Schaffgotsche Werke), Henckel von Donnersmarck (Generaldirektion Fürst von Donnersmarck) oraz spadkobierców Gieschego (Bergwerksgeseltschaft Georg von Giesche's Erben). Przedstawiciele wymienionych koncernów przez liczne apele i rozmowy w kręgach wysoko postawionych nazistowskich urzędników i działaczy starali się wskazać na ogromne trudności wynikające z podziału górnośląskiego przemysłu, ale zarazem na możliwości jego rozbudowy po ewentualnym scaleniu. Wyrażali przy tym chęć podjęcia się tego trudu i przejęcia tych zakładów ${ }^{19}$. Oprócz obecnych już na rynku górnośląskich potentatów przemysłowych, swoje zainteresowanie złożami surowców i górnośląskim przemysłem wykazywali inni wielcy przemysłowcy niemieccy, jak koncern przemysłu stalowego Friedricha Flicka ${ }^{20}$, IG Farbenindustrie A.G., a przejściowo także koncerny Krupp A.G. z Zagłębia Ruhry i Roberta Röchlinga z Zagłębia Saary. Jednak największe zainteresowanie i dążenie do przejęcia możliwie dużej ilości zakładów przejawiał koncern Reichswerke Hermann Göring. Ten ostatni, rozbudowując zakłady przemysłowe z branży hutnictwa żelaza, starał się uniezależnić przez zapewnienie wła-

Treibstoff 1933-1945. Ein Beitrag zur nationalistischen Wirtschafts- und Rüstungspolitik, Berlin - Frankfurt 1964, s. 137-139; H. Petzina, Der nationalsozialistische Vierjahresplan von 1936, Mannheim 1965.

${ }^{19}$ A. Sulik, Przemyst ciężki..., s. 26-27.

${ }^{20}$ Do 1935 r. był on posiadaczem udziałów - za pośrednictwem amerykańsko-niemieckiego holdingu Consolidated Silesian Steel Corporation z siedzibą w Nowym Jorku - w firmie Górnośląskie Zjednoczone Huty Królewska i Laura. Spółka Akcyjna Górniczo-Hutnicza (w której udziałowcem był także Skarb Państwa) i Katowickiej Spółce Akcyjnej dla Górnictwa i Hutnictwa. W 1936 r. obie firmy zostały przejęte przez Wspólnotę Interesów Górniczo-Hutniczych, w której większościowy pakiet posiadało państwo polskie. Zob. J. Popkiewicz, F. Ryszka, op. cit., s. 425-429. Zob. również: J. Jaros, Tajemnice..., s. 128-130; idem, Historia górnictwa węglowego w latach 1914-1945, Katowice 1969, s. 172-174. 
snej bazy paliwowej w postaci kopalń węgla kamiennego ${ }^{21}$. Górny Śląsk przedstawiano też jako alternatywę dla pozostałych dwóch większych zagłębi przemysłowych III Rzeszy (Ruhry i Saary), zagrożonych możliwym wtargnięciem wojsk francuskich podczas wojny. Region posiadał dogodne położenie geopolityczne ułatwiające eksport wyrobów do krajów w Europie Środkowo-Wschodniej (Węgry, Rumunia, Bułgaria) celem umocnienia swojej pozycji eksportera, a w przypadku realizacji planu ekspansji na wschód był bliską bazą zaopatrzeniową.

Wraz z niemieckimi przygotowaniami do agresji na Polskę, z inicjatywy poszczególnych koncernów przemysłowych oraz Ministerstwa Gospodarki Rzeszy (Reichswirtschaftsministerium) i działającego przy Naczelnym Dowództwie Wehrmachtu (Oberkomando der Wehrmacht, OKW) Sztabu Zagranicznego Gospodarki Wojennej, wykonano szereg analiz i raportów o stanie i zdolnościach produkcyjnych górnośląskiego i zagłębiowskiego górnictwa i hutnictwa. Dane te miały posłużyć do dwóch zasadniczych celów: poznania silnych i słabych stron polskiej gospodarki oraz możliwości jej ewentualnego wykorzystania, a także porównania $\mathrm{z}$ danymi dotyczącymi macierzystej gospodarki. W tych opracowaniach wskazano na uzyskane pod koniec lat 30. nadwyżki surowców - węgla i galmanu (rudy cynku), oraz na ograniczone możliwości pełnego wykorzystania potencjału gospodarczego Górnego Śląska ze względu na mało chłonny rynek krajowy. Odnosiło się to zwłaszcza do hutnictwa cynku. Wspólnym dla wszystkich tych opracowań wnioskiem była możliwość wykorzystania zasobów i technologii polskiego Górnego Śląska przy jednoczesnym jego doinwestowaniu i modernizacji.

$\mathrm{W}$ przededniu wybuchu niemiecko-polskiego konfliktu i realizacji założeń planu „Fall Weiß” OKW wydało szczegółowe instrukcje dotyczące przejmowania górnośląskich zakładów w stanie nienaruszonym, w celu ich możliwie szybkiego uruchomienia dla potrzeb przemysłu zbrojeniowego III Rzeszy. Rozkazem OKW z 17 sierpnia 1939 r. utworzono sztab kierowniczy do zadań specjalnych (Verwaltungsstab für Sonderaufgabe), na czele którego stanął dotychczasowy prezes Okręgowej Izby Gospodarczej we Wrocławiu (Gauwirtschaftskammer zu Breslau) - Otto Fitzner. W skład sztabu weszli także starostowie i oddział gospodarki wojennej przy Armii Południe. Hierarchicznie podlegał on bezpośrednio nadprezydentowi prowincji śląskiej, gauleiterowi Josefowi Wagnerowi. Sztab został podzielony na kilka wydziałów zajmujących się określonymi dziedzinami (bankami, rolnictwem, zatrudnieniem, podatkami i cłami, gospodarką leśną, przemysłem, gospodarką komunalną i zarządem komisarycznym). W porozumieniu ze specjalnym pełnomocnikiem do spraw gospodarczych (Sonderbeautragter der GBW) szef sztabu przygotował listę potencjalnych osób, które miały stanąć na czele zakładów przemysłowych oraz Okręgowych Urzędów Górniczych w Kato-

${ }^{21}$ M. Riedel, Eisen und Kohle für das Dritte Reich. Paul Pleiger in der NS-Wirtschaft, Göttingen - Franfurt 1973, s. 300-305. 
wicach, Tarnowskich Górach, Chorzowie i Rybniku²2. Jak już wspomniano wcześniej, przejęcie Górnego Śląska dawało Niemcom korzyści w postaci pozyskania trzeciego dużego okręgu przemysłowego, o potencjale większym (przez przyłączenie Zagłębia Dąbrowskiego, Zagłębia Krakowskiego i Zagłębia OstrawskoKarwińskiego) niż Zagłębie Saary, zagrożonego bliskością granicy z Francją ${ }^{23}$.

\section{KONSEKWENCJE WRZEŚNIA 1939 R. DLA PRZEMYSŁU GÓRNOŚLĄSKIEGO}

Wybuch 1 września 1939 r. wojny polsko-niemieckiej, która przerodziła się kilka dni później w konflikt światowy, doprowadził do poważnych zmian w dotychczasowym układzie politycznym, gospodarczym i społecznym na Górnym Śląsku. W ciągu pierwszych trzech dni konflikt miał charakter walk granicznych pomiędzy zgrupowanymi na Górnym Śląsku oddziałami najsilniejszej polskiej Armii „Kraków”, wspomaganej przez wydzielone Grupy Operacyjne „Śląsk” (w ramach umocnionego Obszaru Warownego Śląsk) i „Bielsko” oraz Bataliony Obrony Narodowej (w skład których weszli byli powstańcy śląscy i młodzież) a niemieckimi oddziałami 10 i 14 Armii (wchodzącymi w ramach Grupy Armii „Południe”), wspomaganymi dodatkowo przez miejscowe grupy SA (Sturmabteilung, Oddziały Szturmowe) i Freikorps ${ }^{24}$. W wyniku przełamania polskiej obrony pod Częstochową (rozgromienie 7 Dywizji Piechoty) i Pszczyną (rozbicie 6 DP) już 2 września Górny Śląsk i broniące go polskie oddziały znalazły się w sytuacji zagrożenia okrążeniem. W tych okolicznościach dowodzący armią gen. Antoni Szyling zdecydował o nocnym, z 2 na 3 września, odwrocie wojsk na linię Wisły i Przemszy ${ }^{25}$. W wyniku tej decyzji cały potencjał gospodarczy polskiego Górnego Śląska w stanie prawie nienaruszonym znalazł się w rękach niemieckich.

Pomijając całkowicie kwestie związane z administracją wojskową na tym terenie we wrześniu i październiku 1939 r., a następnie zmiany w podziale administracyjnym, które zostały dosyć dobrze opisane w literaturze, skupię się wyłącznie na sprawach administracji gospodarczej ${ }^{26}$. Już w pierwszych dniach września 1939 r. oddziały techniczne, działające w ramach Inspekcji Gospodarki Wojennej VIII Okręgu Wojskowego we Wrocławiu (współpracujące z cywilnym sztabem kierowniczym do zadań specjalnych), uruchamiały produkcję. Bez większych

\footnotetext{
${ }^{22}$ A. Sulik, Przemyst ciężki..., s. 30.

${ }^{23}$ G. Hass, Deutschland im Zweiten Weltkrieg, Bd. 1, Berlin 1975, s. 164.

${ }^{24}$ Szerzej na temat działań wojennych na Górnym Śląsku w 1939 r. zob. R. Kaczmarek, Górny Ślask podczas II wojny światowej, Katowice 2006, s. 47-71.

${ }_{25}$ Ostatecznie na skutek odwrotów taktycznych zdołał przeprowadzić swoje oddziały na Lubelszczyznę, gdzie zostały przeformowane do nowo utworzonej Armii „Lublin” (pod dowództwem gen. Tadeusza Piskora) i wzięły udział w I bitwie pod Tomaszowem Lubelskim (1720 września 1939 r.). Zob. P. Wieczorkiewicz, Kampania 1939 roku, Warszawa 2001.

${ }^{26}$ R. Kaczmarek, op. cit., s. 82-130.
} 
komplikacji nastąpiło to w górnictwie węglowym, ponieważ 10 września raportowano, że praktycznie wszystkie górnośląskie kopalnie wznowiły wydobycie, ale przy stanie załóg kształtującym się na poziomie $50-70 \%{ }^{27}$. Pięć dni później pracowało także osiem zakładów w Zagłębiu Dąbrowskim i Zagłębiu Krakowskim ${ }^{28}$. Równie szybko zapewniono dostawy energii elektrycznej z elektrowni w Chorzowie, Łaziskach, Rudzie, Będzinie i Jaworznie, które uruchomiono pomiędzy 4 a 8 września 1939 r. ${ }^{29}$

Znacznie gorzej wyglądała sytuacja w hutnictwie żelaza. Do połowy września udało się uruchomić - i to w dodatku tylko częściowo - trzy huty: „Batory”, „Pokój” i „Piłsudski”. Ostatecznie do końca miesiąca zdołano wznowić produkcję we wszystkich zakładach Górnego Śląska oraz dwóch w Zagłębiu Dąbrowskim (huty „Bankowa” i „Sosnowiec”; pozostałe tamtejsze zakłady przeznaczono do likwidacji ze względu na przestarzałą technologię) ${ }^{30}$. Ponadto rozpoczęto prace analityczne (trwające do wiosny 1940 r.), w wyniku których sporządzono szczegółowy wykaz majątku przemysłowego. Spośród najważniejszych zakładów okupant przeją: 70 kopalń węgla kamiennego, 15 koksowni, cztery brykietownie, dwie kopalnie rud cynku i ołowiu, 10 hut cynku (i jedną hutę ołowiu i srebra w Strzybnicy) oraz ponad 30 hut i walcowni żelaza ${ }^{31}$. Główną korzyścią z przejęcia tutejszego przemysłu było podniesienie zdolności wydobycia węgla w III Rzeszy o 55-60 mln ton rocznie oraz znaczący, bo szacowany na $150 \%$, wzrost zapasów węgla ${ }^{32}$. Wzrósł także poziom produkcji koksu o $7 \mathrm{mln}$ ton. Przejęto poważny liczebnie potencjał przemysłowy w hutnictwie żelaza (62 piece martenowskie, 26 wielkich pieców, siedem pieców elektrycznych), a jego wytwórczość wynosiła 1,2 mln ton surówki, 2,1 mln ton stali oraz 1,3 mln ton wyrobów walcowanych. Zajęcie tych zakładów było poważnym ,zastrzykiem” dla gospodarki III Rzeszy, która stała się obok USA drugim na świecie potentatem produkcji żelaza i stali33. Inną równie ważną przejętą gałęzią przemysłu było hutnictwo cynku, szczególnie w kontekście faktu, że Polska międzywojenna była jednym z czołowych producentów cynku z roczną produkcją 180 tys. ton.

${ }^{27}$ Archiwum Państwowe Katowice, Główny Urzą Powierniczy Wschód, Urząd Powierniczy w Katowicach, zesp. 124, sygn. 3156, sprawozdanie z 15 września 1939 r.

${ }^{28}$ Archiwum Państwowe Katowice, Gtówny Urząd Powierniczy Wschód, Urząd Powierniczy w Katowicach, zesp. 124, sygn. 2922, sprawozdanie z 16 września 1939 r.

${ }^{29}$ Archiwum Państwowe Katowice, Główny Urząd Powierniczy Wschód, Urząd Powierniczy w Katowicach, zesp. 124, sygn. 3056, sprawozdanie z 10 września 1939 r.

${ }^{30}$ Archiwum Państwowe Katowice, Główny Urząd Powierniczy Wschód, Urząd Powierniczy w Katowicach, zesp. 124, sygn. 2918, s. 4.

${ }^{31}$ Archiwum Państwowe Katowice, Urzad do Spraw Planowania Przestrzenno-Budowlanego dla Górnego Śląska Oddział Okręgowy w Katowicach, zesp. 120, sygn. 228, zestawienie z 5 października $1939 \mathrm{r}$.

${ }^{32}$ Ibidem, sygn. 67.

${ }^{33}$ Dane z 1938 r. Zob. G. Behagel, Der Aufbau der Industrie Oberschlesiens im Wechsel der Zeiten und Wirtschafteräume, „Stahl und Eisen“ 1940, z. 5, s. 98-100. 
Oprócz ponownego uruchamiania zakładów przemysłowych i przeprowadzania licznych analiz ekonomicznych dokonano również konfiskaty znajdujących się w przedsiębiorstwach surowców, półfabrykatów i maszyn (pod pretekstem wzmocnienia gospodarki państwa). Nie wzięto przy tym pod uwagę stosunków własnościowych. Mianowano od razu nowych kierowników zakładów, zarówno spośród dawnych kadr inżynierskich, usuniętych w latach 30. XX w. przez polskie władze, jak i z grup urzędniczych przybyłych z głębi Rzeszy. Głównym kryterium mianowania na stanowiska nie było wykształcenie i doświadczenie, lecz czystość rasowa, przynależność partyjna i zasługi dla III Rzeszy oraz ewentualnie działalność w górnośląskich strukturach Volksbundu i Jungdeutsche Partei. Powodowało to, że nominacje odbywały się z klucza partyjnego ${ }^{34}$. Wznowiono poza tym działalność administracji specjalnej (urzędów górniczych) i organizacji przemysłowych, chociaż w przypadku tych ostatnich zaszły poważne zmiany. Obowiązki dotychczasowych związków, syndykatów i karteli przejęły ich niemieckie odpowiedniki z dawnej zachodniej części Górnego Śląska, głównie Oberschlesischer Berg und Hüttenmännischer Verein (Górnośląski Związek Przemysłowców Górniczo-Hutniczych) i Stahlwerksverband (Związek Przemysłu Hutniczego), których filie utworzono w Katowicach, oraz Oberschlesisches Steinkohlensyndikat z Gliwic (Górnośląski Syndykat Węgla Kamiennego).

Nieco inna sytuacja miała miejsce w Zagłębiu Dąbrowskim i Zagłębiu Krakowskim, gdzie wobec braku zainteresowania przyjęciem stanowisk kierowniczych ustanawiano 3-osobowe grupy zarządzające (złożone $\mathrm{z}$ pochodzącego z Rzeszy urzędnika i dwóch miejscowych inżynierów).

Od pierwszych dni września, mimo funkcjonowania zarządu wojskowego, władze niemieckie traktowały Górny Śląsk wraz z przyległymi terenami jako integralną część III Rzeszy. Wspomniany obszar obejmował, oprócz wschodniej części Górnego Śląska, także Zagłębie Dąbrowskie, Zagłębie Krakowskie, Zagłębie Ostrawsko-Karwińskie oraz Żywiecczyznę, powiaty: lubliniecki, zawierciański i część blachowieńskiego. Należy przy tym podkreślić, iż takie ukształtowanie granic powstałej 26 października 1939 r. rejencji katowickiej (trzy ostatnie wymienione powiaty przyłączono do rejencji opolskiej) wywołało liczne dyskusje w kręgach polityków, wojskowych i przemysłowców ${ }^{35}$. Ostatecznie o przebiegu granicy zdecydowały nie tyle czynniki narodowościowe, co względy gospodar-

\footnotetext{
${ }^{34}$ Archiwum Państwowe Katowice, Huta „Pokój” Ślaskie Zakłady Górniczo-Hutnicze S.A. w Katowicach, zesp. 489 (dalej Huta Pokój), sygn. 7.

${ }^{35}$ Dekret A. Hitlera „O podziale i zarządzie terenów wschodnich”, wcielający m.in. Górny Śląsk do Rzeszy, został wydany 8 października 1939 r., z dniem wejścia w życie 26 października tego roku. Dekret ten jednak nie precyzował granic nowej rejencji, ukształtowały się one w toku ustaleń pomiędzy władzami Generalnego Gubernatorstwa, dowództwem VIII Okręgu Wojskowego we Wrocławiu i Pełnomocnikiem do wykonania planu 4-letniego. Zob. R. Kaczmarek, op. cit., s. 96-97.
} 
cze. Wynikało to z podjęcia decyzji o stworzeniu warunków do możliwie racjonalnego wykorzystania potencjału przemysłowego, połączonego w jeden organizm $^{36}$. Spotkało się to z zadowoleniem przemysłowców zainteresowanych wykorzystaniem Zagłębia Dąbrowskiego dla potrzeb gospodarki zbrojeniowej, a równocześnie $\mathrm{z}$ oporem i niechęcią części działaczy partyjnych wobec zanegowania polityki rasowej i potrzeby szybkiej poprawy sytuacji socjalnej mieszkańców.

Tajnym rozporządzeniem pełnomocnika do spraw planu 4-letniego - Hermanna Göringa, uregulowano kwestię przejęcia polskiego mienia przemysłowego i prywatnego.

W tym celu 1 listopada 1939 r. utworzono w Berlinie Główny Urząd Powierniczy Wschód (Haputtreuhandstelle Ost, HTO) ${ }^{37}$. Najważniejszymi zadaniami tego urzędu były konfiskata i zarząd mieniem byłego państwa polskiego oraz jego obywateli, a następnie uregulowanie jego statusu prawnego i zbycie przejętego majątku na rzecz nowych właścicieli. Współpracowano przy tym z Komisariatem Rzeszy do spraw Umacniania Niemczyzny (Stabshauptamt Reichkomissar für die Festigung deutsches Volkstums), na czele którego stał Reichsführer SS Heinrich Himmler. Jako że twórcą HTO był H. Göring, zapewnił on sobie w ten sposób prawo decyzji zajęcia poszczególnych zakładów na terenach anektowanych do Rzeszy. Często korzystał z tego uprawnienia, przejmując największe i najbardziej dochodowe zakłady przemysłowe dla państwowego koncernu Reichswerke Hermann Göring $\mathrm{GmbH}$, pod pretekstem ich ogromnego znaczenia dla dobra publicznego, obronności lub umacniania niemczyzny ${ }^{38}$. W tym samym czasie w Katowicach powstała ekspozytura HTO, na czele ze wspomnianym już wcześniej O. Fitznerem (a następnie kolejno dr. A. Jacobem, a od 1941 r. dr. H. Matouschką) $)^{39}$. Katowicka delegatura, oprócz zewidencjonowania podległych sobie zakładów przemysłowych, handlowych czy rzemieślniczych (na terenie rejencji łącznie 25397 obiektów), dokonała ich przejęcia, mianując zarządy komisaryczne. Były one w większości złożone z reichs- lub volksdeutschów (na ogół nie byli inżynierami lub ekonomistami), co budziło zastrzeżenia w kwestii braku kwalifikacji lub racjonalnego gospodarowania ${ }^{40}$. Ponadto część zarządów komisarycznych pełniły niemieckie koncerny lub firmy. Przykład stanowi zarząd nad spółkami Górnośląskie Kopalnie i Cynkownie w Lipinach, powie-

${ }^{36}$ I. Sroka, Górny Śląsk i Zagłębie Dąbrowskie pod okupacyjnym zarządem wojskowym, Katowice 1975, s. 106-107.

${ }^{37}$ W. Jastrzębowski, Gospodarka niemiecka w Polsce (1939-1944), Warszawa 1946, s. 191-196.

${ }^{38}$ Przykładem tego było przejęcie kopalń Skarbofermu i Rybnickiego Gwarectwa Węglowego.

${ }^{39}$ Początkowo była ona całkowicie niezależna od urzędu prezydenta rejencji i nadprezydenta prowincji. Zmiana nastąpiła wraz z rozporządzeniem H. Göringa z 17 lutego 1941 r., na mocy którego Urząd Powierniczy w Katowicach został podporządkowany nadprezydentowi prowincji górnośląskiej Fritzowi Brachtowi. Zob. A. Sulik, Przemyst ciężki..., s. 66-67.

${ }^{40}$ Ibidem. 
rzony „Schlesag’owi” majątek „Huty Pokój S.A.” został przekazany koncernowi hrabiego Ballestrema, a zakłady i kopalnie Giesche S.A. zostały przekształcone w nową spółkę Gieschebetriebe ${ }^{41}$. Mianowanie zarządów komisarycznych w zakładach przemysłowych miało w założeniu charakter przejściowy, gdyż HTO było zobowiązane do odpłatnego zbycia majątku właścicielom prywatnym w możliwie najszybszym czasie, po uregulowaniu wcześniejszych wierzytelności i zadłużeń (nie dotyczyło to przedwojennych zobowiązań). Nierzadko wartość zakładów zawyżano lub zaniżano, w zależności od tego, kto był jego nabywcą ${ }^{42}$. Miało to związek z rywalizacją przemysłowców zachodniogórnośląskich, takich jak hrabiowie von Ballestrem, Henckel von Donnersmarck, Schaffgotsch, Hohenlohe-Ingelfingen oraz spadkobiercy Gieschego, z przemysłowcami z Zagłębia Ruhry i Saary, a także faworyzowaniem tych ostatnich przez HTO i władze III Rze$\mathrm{szy}^{43}$. Ci pierwsi przejęcie zakładów traktowali jako naprawienie krzywd wyrządzonych przez niesprawiedliwy podział Górnego Śląska i decyzję władz polskich oraz uzasadniali to znajomością tutejszych stosunków społecznych i realną możliwością doinwestowania zakładów. Należy podkreślić, iż stopień zainteresowania zakładami przemysłowymi był różny, poczynając od utraconych zakładów, a kończąc na potencjalnych zakładach z Zagłębia Dąbrowskiego czy Zagłębia Krakowskiego. Przykładem zachłanności była postawa hrabiego von Ballestrema, który w zamian za zasługi w rozwoju niemieckiego przemysłu zbrojeniowego w latach 1938-1939 liczył na otrzymanie utraconych hut „Pokój”, „Ferrum” i „Baildon” oraz całego majątku Wspólnoty Interesów, przewidzianego do wchłonięcia przez „Oberhütten” ${ }^{44}$. Z kolei dla drugiej grupy przemysłowców górnośląskie zakłady ze względu na swoje dogodne położenie stanowiły alternatywę dla macierzystych przedsiębiorstw zagrożonych nalotami lub zajęciem w Zagłębiach Ruhry i Saary.

Jak już wcześniej wspomniano, głównym zainteresowanym z tej grupy kapitałowej był koncern Hermann Göring GmbH, który wykorzystał decyzję o zaliczeniu 62 kopalń i koksowni do grupy zakładów zmilitaryzowanych (W-Betriebe), podlegających bezpośredniemu zwierzchnictwu Pełnomocnika do spraw planu 4-letniego ${ }^{45}$. Dzięki temu koncern przejął największe górnośląskie zakłady górnicze, ograniczając tym samym konkurencyjność w branży hutnictwa żelaza. Po-

${ }^{41}$ Archiwum Państwowe Katowice, Syndykat Polskich Hut Żelaza, zesp. 368, sygn. 170.

${ }^{42}$ A. Sulik, Przemyst ciężki..., s. $78-80$.

${ }^{43}$ Ibidem, s. 81-83, 113.

${ }^{44}$ Ibidem, s. 113-114.

${ }^{45}$ Działania te miały na celu zbudowanie samowystarczalnego koncernu, wzorowanego na amerykańskim truście United Steel Corporation. Z drugiej strony spotkało się to z oporem zachodniogórnośląskich przemysłowców, którzy traktowali te działania jako podważające dotychczasowe zasady niezależności górnictwa oraz egzystencji hutnictwa na Górnym Śląsku. Zob. Archiwum Państwowe Katowice, Górnoślaski Związek Przemysłowców Górniczo-Hutniczych w Gliwicach Delegatura w Katowicach, zesp. 328, sygn. 21. 
dobna sytuacja miała miejsce w przypadku górnośląskich elektrowni. Władze rejencji zamierzały je utrzymać pod swoim zarządem lub przekazać miejscowym koncernom. O ich losie przesądziła jednak decyzja władz centralnych, które doprowadziły do ich skoncentrowania $\mathrm{w}$ rękach państwowego przedsiębiorstwa. Działania te doprowadziły do licznych dyskusji i krytyki związanej z ograniczeniem w zakresie stosunków własnościowych czy sprzedaży majątku przemysłowego. Konsekwencją tej decyzji był spadek zainteresowania innych koncernów niemieckich przejęciem pozostałych zakładów przemysłowych, a zwłaszcza hut żelaza. Wobec niemożności zapewnienia niezależnej bazy paliwowej ze starań o przejęcie górnośląskich zakładów hutniczych wycofały się m.in. koncerny Friedricha Flicka, Hermana Röchlinga czy Alfreda Kruppa ${ }^{46}$. Jeszcze gorsza sytuacja kształtowała się w przypadku zakładów hutniczych w Zagłębiu Dąbrowskim, które uważano w przeważającej większości jako przestarzałe i nierentowne (wyjątek stanowiła huta „Bankowa”). W efekcie przedsiębiorstwa te właściwie do końca wojny pozostawały w zarządzie komisarycznym. Nieco inaczej kształtowała się sprawa z tamtejszymi kopalniami węgla, gdzie - wobec braku większego zainteresowania ich nabyciem - zakłady te zostały przekazane dwóm podmiotom: państwowemu koncernowi Preussag oraz firmie Saturn A.G. w Czeladzi ${ }^{47}$.

Kolejne klęski i pogorszenie sytuacji militarnej na froncie wschodnim spowodowały mobilizację wszystkich zasobów i rezerw technologicznych w gospodarce, dając jednocześnie pierwszeństwo przemysłowi zbrojeniowemu. Równolegle wstrzymywano realizację planów modernizacyjnych i rozwojowych przemysłu w rejencji katowickiej, a nawet wznawiano produkcję w wielu unieruchomionych na przełomie 1939 i 1940 r. przestarzałych zakładach. Dążenie do realizacji założeń produkcyjnych skutkowało nasileniem się rabunkowej eksploatacji w górnictwie i stosowaniem przemocy wobec robotników ${ }^{48}$.

Wraz z inwazją aliantów na Normandię latem 1944 r. wzrosła rola przemysłu Górnego Śląska wobec zagrożenia zachodnioniemieckich ośrodków przemysłowych. W tym okresie region ten stał się czołowym producentem węgla oraz wyrobów żelaznych i cynkowych. Wysoki poziom produkcyjny utrzymywał się właściwie do ostatnich dni przed wznowieniem działań wojennych na froncie wschodnim i realizacji przez I Front Ukraiński operacji sandomiersko-śląskiej W styczniu $1945 \mathrm{r}$. Wraz z utratą potencjału przemysłowego i bazy surowcowej na Górnym Śląsku, Wehrmacht został pozbawiony zabezpieczenia potrzeb zbrojeniowych oraz została zagrożona żegluga bałtycka poprzez przecięcie przez front magistrali węglowej Śląsk - Gdynia. Zajęcie przez Armię Czerwoną okręgu przemysłowego w drugiej połowie stycznia 1945 r. przyspieszyło jedynie załamanie gospodarcze III Rzeszy.

\footnotetext{
${ }^{46}$ A. Sulik, Przemyst ciężki..., s. 114-115, 121-125.

${ }^{47}$ Ibidem, s. 147-151.

${ }^{48}$ J. Kisiel, F. Rudzki, 125 lat „Huty Pokój”, Ruda Śląska 1965, s. 67.
} 


\section{BIBLIOGRAFIA}

\section{Źródla}

Archiwum Państwowe Gliwice, Grupa Okręgowa Górnictwo Węgla Kamiennego na Górnym Ślasku Grupy Gospodarczej Górnictwo w Gliwicach, zesp. 120, sygn. 323.

Archiwum Państwowe Katowice, Górnośląski Zwiąek Przemysłowców Górniczo-Hutniczych w Gliwicach Delegatura w Katowicach, zesp. 328, sygn. 21.

Archiwum Państwowe Katowice, Huta „Pokój” Śląskie Zakłady Górniczo-Hutnicze S.A. w Katowicach, zesp. 489.

Archiwum Państwowe Katowice, Polska Huta Skarbowa Olowiu i Srebra w Strzybnicy, zesp. 1533.

Archiwum Państwowe Katowice, Syndykat Polskich Hut Żelaza, zesp. 368, sygn. 170.

Archiwum Państwowe Katowice, Urząd do Spraw Planowania Przestrzenno-Budowlanego dla Górnego Ślaska Oddziat Okręgowy w Katowicach, zesp. 120, sygn. 228, zestawienie z 5 października $1939 \mathrm{r}$.

Archiwum Państwowe Katowice, Główny Urząd Powierniczy Wschód, Urzad Powierniczy w Katowicach, zesp. 124, sygn. 3156, sprawozdanie z 15 września 1939 r.

Archiwum Państwowe Katowice, Główny Urząd Powierniczy Wschód, Urząd Powierniczy w Katowicach, zesp. 124, sygn. 2918.

Archiwum Państwowe Katowice, Główny Urząd Powierniczy Wschód, Urząd Powierniczy w Katowicach, zesp. 124, sygn. 2922, sprawozdanie z 16 września 1939 r.

Archiwum Państwowe Katowice, Główny Urząd Powierniczy Wschód, Urząd Powierniczy w Katowicach, zesp. 124, sygn. 3056, sprawozdanie z 10 września 1939 r.

Archiwum Państwowe Katowice, SKARBOFERM Spółka Dzierżawna Polskich Kopalń Skarbowych na Górnym Śląsku Spótka Akcyjna w Katowicach, zesp. 334.

\section{Opracowania}

Behagel G., Der Aufbau der Industrie Oberschlesiens im Wechsel der Zeiten und Wirtschafteräume, „Stahl und Eisen“ 1940, z. 5.

Biały F., Górnośląski Zwiąek Przemysłowców Górniczo-Hutniczych (1914-1932), Wrocław - Warszawa-Kraków 1967.

Birkenfeld W., Der syntetische Treibstoff 1933-1945. Ein Beitrag zur nationalistischen Wirtschaftsund Rüstungspolitik, Berlin - Frankfurt 1964.

Błachut K., Polsko-niemieckie stosunki gospodarcze w latach 1919-1939, Wrocław 1975.

Grzyb M., Narodowościowo-polityczne aspekty przemian stosunków własnościowych i kadrowych w górnośląskim przemyśle w latach 1922-1939, Katowice 1978.

Hass G., Deutschland im Zweiten Weltkrieg, Bd. 1, Berlin 1975.

Jaros J., Historia górnictwa węlowego w latach 1914-1945, Katowice 1969.

Jaros J., Tajemnice górnośląskich koncernów, Katowice 1988.

Jastrzębowski W., Gospodarka niemiecka w Polsce (1939-1944), Warszawa 1946.

Kaczmarek R., Górny Śląk podczas II wojny światowej, Katowice 2006.

Kisiel J., Rudzki F., 125 lat „Huty Pokój”, Ruda Śląska 1965.

Petzina H., Der nationalsozialistische Vierjahresplan von 1936, Mannheim 1965.

Popkiewicz J., Ryszka F., Przemyst ciężki Górnego Śląsa w gospodarce Polski międzywojennej (1922-1939), Opole 1959.

Przewłocki J., Stosunek mocarstw zachodnio-europejskich do problemów Górnego Ślaska w latach 1918-1939, Warszawa-Kraków 1978. 
Riedel M., Eisen und Kohle für das Dritte Reich. Paul Pleiger in der NS-Wirtschaft, Göttingen Franfurt 1973.

Smierz M., Polsko-niemiecka konwencja genewska z dnia 15 maja 1922 roku. Założenia i realizacja, [w:] Vade Nobiscum, t. III: Historia dyplomacji, Łódź 2010.

Sroka I., Górny Śląsk i Zagłębie Dąbrowskie pod okupacyjnym zarządem wojskowym, Katowice 1975.

Sulik A., Przemyst, [w:] Województwo śląskie (1922-1939), red. F. Serafin, Katowice 1996.

Sulik A., Przemyst ciężki rejencji katowickiej w gospodarce Trzeciej Rzeszy (1939-1945), Katowice 1984

Szmidtke Z., „Skarboferm” 1922-1939. Zwiazki polityki z gospodarka, Opole 2005.

Wende G., Die Auswirkung der Grenzziehung auf die Oberschlesische Montanindustrie, Stuttgart 1932.

Wieczorkiewicz P., Kampania 1939 roku, Warszawa 2001.

Zakłady Azotowe im. P. Findera - Chorzów, red. A. Topola, Katowice 1979.

\section{SUMMARY}

This article aims to identify what was the impact of mining and metallurgical industry in the Polish part of Upper Silesia in the politics of the Third Reich before and during World War II. The basis of this text is to identify the causes of which were due to increased interest in Upper Silesia in the second half of the 30 s of the $20^{\text {th }}$ century (militarization, stimulating the economy through a series of state investments, and consequently an increase in demand for coal and steel, and an attempt to economic independence from other countries - autarky).

Keywords: Upper Silesia; industry; interwar period; the Third Reich 